\title{
Can resources act as capabilities foundations? A bibliometric analysis
}

\section{¿Pueden los recursos actuar como origen de capacidades? Un análisis bibliométrico}

\author{
Mileidy Álvarez-Melgarejo ${ }^{1}$, Martha Torres-Barreto ${ }^{2}$ \\ ${ }^{1}$ Grupo Porter, Dirección de Investigaciones, Universidad de Investigación y Desarrollo, Colombia. \\ Orcid: http://orcid.org/0000-0003-1752-8023. Email: mileidyalvarez@ hotmail.es \\ ${ }^{2}$ Grupo Finance \& Managament, Escuela de Estudios Industriales y Empresariales, Universidad Industrial de Santander, \\ Colombia. Orcid: http://orcid.org/0000-0002-4388-5991.Email: mltorres@uis.edu.co
}

Received: January 18, 2018. Accepted: March 27, 2018. Final version: April 19, 2018.

\begin{abstract}
The objective of this article is to record the trends of study regarding the relationships between resources and capabilities, through a review of the literature of its definitions and typologies from 1984-2016, followed by a bibliometric analysis during the period 2001-2016. For this analysis, we used records of the Web of Science. The analysis includes indicators of annual productivity, by countries and authors, most productive magazines and most cited articles. A low productivity was identified, 2010 being the year with the largest number of articles published. The United States leads in number of articles related to the topic. The most cited articles were published in 2003 and the most productive authors have 3 publications each. Thus, important academic gaps are evident, which is why future study paths are suggested.
\end{abstract}

Keywords: bibliometric analysis; capabilities; resources; competitive advantage; Web of Science.

\section{Resumen}

El objetivo de este artículo es registrar las tendencias de estudio sobre las relaciones entre los recursos y las capacidades, a través de una revisión de la literatura de sus definiciones y tipologías desde 1984 hasta 2016, seguido de un análisis bibliométrico durante el período 2001-2016. Para este análisis, usamos registros de la Web of Science. El análisis incluye indicadores de productividad anual, por países y autores, revistas más productivas y artículos más citados. Se identificó una baja productividad, 2010 el año con la mayor cantidad de artículos publicados. Estados Unidos lidera en número de artículos relacionados con el tema. Los artículos más citados se publicaron en 2003 y los autores más productivos tienen 3 publicaciones cada uno. Por lo tanto, las brechas académicas importantes son evidentes, por lo que se sugieren caminos de estudio futuros.

Palabras clave: análisis biblimétrico; capacidades; recursos; ventaja competitiva; Web of Science. 


\section{Introduction}

The research on Resource Based View of the Firm (RBV) is one of the most influential tendencies of strategic management, proving this in numerous studies on the relevance of resources and capabilities in terms of generating competitive advantages for companies [1], [2], [3], [4]. The literature suggests that the RBV attempts to answer the enigma of the differences in business performance, specifically: how competitive advantages are obtained? what generates them? what are their scope? and how do organizations sustain them in time?

From the contributions of Penrose (1959) the company was understood as a set of productive resources, later on, the seminal work of Wernerfelt (1984) gave way to the study of the RBV in terms of use, growth, capacity and development of resources that lead to business economic returns. From that moment this theory has been addressed by numerous authors [5], [6], [7], [8], [1], [9], [10], [4], [11], [12], who agree that their study is relevant because it attempts to explain the development of competitive advantages based on the resources and capabilities (R\&C) that companies possess or develop, and indeed, in the literature there are pieces of evidence that show that the integration and perfect combination of $\mathrm{R} \& \mathrm{C}$ translates into the generation of business competitiveness [13], [14], [15], [16], [12]. At this point, one question arises: what resources and what capabilities need to be working together to obtain higher yields compared to those of the competition?

Thus, the objective of this paper is to provide a theoretical basis on the different authors who have addressed the study of $\mathrm{R} \& \mathrm{C}$, actual concepts and classifications of them as well as to analyze the relationships between their approach to literature. Next, there will be a consideration of certain resources that could be generating entrepreneurial skills and, under this dynamic, the companies that own them could enhance a set of capabilities to generate more competitive advantages. The result of the bibliometric review reveals an agenda to follow in future research in this area.

This document begins with the description of resources and capabilities and some classifications, the relationships found in the literature between these two elements are presented below; finishing with the conclusions of the study of this topic and a suggested agenda for researchers who want to delve into this topic.

\section{Theoretical framework}

The RBV tries to explain the paradigm of the differences between the organizations of the same industry in terms of performance and competitiveness. Its initial idea exposes the premise that the company is a set of productive resources that can increase and enhance its value to obtain a competitive advantage [17]. Its study is approached with force from the work of Wernerfelt (1984), who considers the company as a set of resources that are heterogeneously distributed. These differences are persistent over time [18], [19], [17], [4], [20], [69], this heterogeneity would explain the different results between companies. Based on this assumption, researchers have theorized that one of the sources of competitive advantages are the resources, when they possess VRIN attributes, that says they are valuable, rare, inimitable and non-substitutable [5], [4], [12], [20], however, these VRIN resources in dynamic market environments do not persist over time and become outdated [11], [12], additionally they are not very productive by themselves. The types, quantities, qualities and the way resources are used, is what determines the results the company could achieve [1] this is what has been called "routines" or "capabilities" of the companies.

In the literature, numerous studies are identified on the importance of resources for companies in the development of their economic activity [21]. In fact, historically they have generated numerous definitions and classifications; perhaps the most influential is its conception as tangible and intangible assets, which are semi-permanently tied to the company and are controlled by it [5], [10], [11], [20]. Some authors argue that these assets are specific to the company, so it is difficult to imitate them or transfer trade secrets and specialized production facilities [22]. Similarly, Grant (1991) defines resources as inputs used in the production process and, the basic units of analysis, since they represent both the foundation of the company and its capabilities [12]. Table 1 shows a historical set of the different conceptions of the term "Resources".

In terms of the typology of resources, perhaps the most popular is the one that divides them into tangible and intangible [10], [20]. Tangible resources have a physical support of a material nature, they are easy to identify, count, measure and value [15]. Examples of them are: property, plant and machinery. Intangibles resources refer to things that cannot be physically perceived, and are difficult to reproduce and imitate; they are based on information and knowledge. Some examples are brand names, internal knowledge in the technology field and efficient procedures [20]. 
Table 1. Definition of the concept "resources"

\begin{tabular}{|c|c|}
\hline Author & Definitions \\
\hline Wernerfelt (1984) & $\begin{array}{l}\text { Assets (tangible and intangible) } \\
\text { that are semi-permanently } \\
\text { linked to the company. }\end{array}$ \\
\hline Barney (1991) & $\begin{array}{l}\text { Include all assets that the } \\
\text { company owns and can control, } \\
\text { allowing to conceive and } \\
\text { implement strategies to improve } \\
\text { efficiency and effectiveness. }\end{array}$ \\
\hline Grant (1991) & $\begin{array}{l}\text { There are inputs in the } \\
\text { production process, these are } \\
\text { the basic units of internally } \\
\text { analysis within the company. }\end{array}$ \\
\hline $\begin{array}{l}\text { Amit\&Schoemaker } \\
\text { (1993) }\end{array}$ & $\begin{array}{l}\text { Stock of available factors that } \\
\text { are owned by the company or } \\
\text { controlled by it. Becoming final } \\
\text { products or services using a } \\
\text { wide range of other assets of the }\end{array}$ \\
\hline & $\begin{array}{l}\text { company and linkage } \\
\text { mechanisms. }\end{array}$ \\
\hline
\end{tabular}

Teece et al. (1997) These are specific company assets that are difficult, if not impossible to imitate and difficult to transfer between companies due to transaction cost.

Navas \&Wars Set of factors or assets that a (2002) company has to carry out its strategy.

Helfat\&Peteraf Assets or contribution to (2003)

Ray, Barney, \& Muhanna (2004) Wang \& Ahmed
$(2007)$

Barreto (2010) production (tangible or intangible) an organization possess, controls or has access on a semi-permanent basis.

Tangible and intangible assets that companies use to develop and implement their strategies.

These are the foundation of the company, fundamental for the development of the capabilities and potential sources of competitive advantage when these have VRIN attributes.

These are stocks of available factors owned or controlled by the company.

Other categories have also been stated, for example: physical, financial, human capital, technological and organizational resources [1], [5], [10], [18]. The physical resources are those used to develop the economic activity and the achievement of goals within the company (plant, equipment, geographical location and access to raw materials); The financial ones are those necessary to cover the costs of the other resources involved (cash, stocks, credits and investments). Given their tangible nature, these resources can be identified and valued more easily through the information provided by the financial statements [1], [10], [14], [15]. The human resource does not refer to the human being as such, it refers to their knowledge, training, experience, intelligence, loyalty and reasoning skills [10], [15]. The technological resources would be constituted by the technological knowledge available that allows the development of products, being specified in patents and databases [10], [15].

Finally, organizational resources include the organizational structure, the line of authority, brand, reputation, among others. Table 2 shows the different classifications of resources found in the literature.

On the other hand, the capabilities have also been studied, and the results are well documented in the literature [23], [22], [21]. Some researchers consider that it is necessary for the capabilities to be internally and externally exploited by the organization [12], [17], [20], [23] in order to recognize, detect, identify, discover and develop opportunities that are necessary for business success [24], since the sustainability of capabilities varies with the dynamism of the market [25]. Considering that these are inherent skills of the personnel and the organization, the capabilities should be understood as organizational structures and managerial processes that support productive activity [23].

They do not come spontaneously; these are routines that are developed from the interaction between the resources and the companies [18], [23], [27], [28]. As a result, capabilities are considered a source for competitive advantage, since not all companies can have and adopt them in the same way and under the same conditions since it is not possible to buy them in the market as any resource, they are created and developed within the organization, this makes them unique, difficult to imitate, transfer and duplicate [29]. 
Table 2. Classification of resources.

\begin{tabular}{|c|c|}
\hline Author & Classifications \\
\hline Wernerfelt (1984) & $\begin{array}{l}\text { Tangible resources (qualified work force, business contacts, machinery). } \\
\text { Intangible assets (brand name, inside knowledge of technology, efficient procedures). }\end{array}$ \\
\hline Wernerfelt (1989) & $\begin{array}{l}\text { Resources with long-term capacity (plant, equipment, employees with specific training, } \\
\text { investments from suppliers or distributors). } \\
\text { Resources with unlimited capacity (patents, brand names and reputation). } \\
\text { Limited resources and unlimited capacity for long term. }\end{array}$ \\
\hline Barney (1991) & $\begin{array}{l}\text { Physical capital (physical technology, plant, equipment, geographic location and access to } \\
\text { raw materials). } \\
\text { human capital (training, experience, intelligence, relationships, managers understanding } \\
\text { and employees of the company). } \\
\text { Organizational capital (formal structure reporting, formal and informal planning systems, } \\
\text { control, coordination, and informal relationships between internal groups) and with their } \\
\text { environment). }\end{array}$ \\
\hline Grant (1991) & Financial, physical, human, technological, reputation, organizational. \\
\hline $\begin{array}{l}\text { Amit \& Schoemaker } \\
(1993)\end{array}$ & Knowledge resources, financial or physical assets and human capital. \\
\hline Navas \& Wars (2002) & $\begin{array}{l}\text { Tangible resources: Physical (land, buildings, machinery, equipment, raw materials, } \\
\text { finished products) and financial (capital, reserves, receivables, shares). } \\
\text { Intangible non-human resources: Technological (patents, designs, databases, know-how) } \\
\text { and Organizational (Brand name, prestige, customer base, organizational design, } \\
\text { reputation, corporate image) } \\
\text { intangible human resources (knowledge, experience, loyalty, motivation, adaptability, } \\
\text { reasoning ability and decision). }\end{array}$ \\
\hline
\end{tabular}

Several experts agree that the capabilities are different constructs integrated in the companies to generate competitive development, there is a set of skills and knowledge of a company to deploy a team of resources working and interacting together achieving a desired end [1], [12], [18]. For example, Teece et al. (1997) argue that the term refers to the key role of strategic management in adapting, integrating and reconfiguring internal and external organizational skills, resources and functional competencies to meet the needs of a changing environment. However, they have been defined as a set of routines that imply the stability and repeatability of the behaviors and processes of an organization [1], [2], [28], [30], [31], this indicates that for the execution and development of a capability, a process of integration and combination of resources is required and its effectiveness will be achieved through repetition, becoming routine [1], [25]; therefore, a routine is necessary for operational efficiency [24] and the creation of tacit knowledge [28], [32]. Scholars who have addressed the issue suggest that the traditional conception of routines applies to relatively static, stable or predictably changing environments, whose process relies on existing knowledge [12], [24], [25]; In contrast, for high-speed exchange environments, a distinctive type of capability is required to respond to the dynamism of the market, these are called dynamic capabilities and they are based on the generation of new knowledge [11], [12], [23], [25], [33]. Table 3 presents different conceptions of the term capabilities over time.

Capabilities, just like resources, have been the subject of numerous classifications throughout academic history, suggesting that they can go from basic and common to advanced, scarce and strategically important capabilities [16]. The literature distinguishes a considerable variety of capabilities that operate in stable and dynamic environments [22], [25], [33], [2], [37]. Recently research has identified and categorize capabilities in three levels [32], [38], level zero or ordinary (allowing the company to earn its livelihood), first level or dynamic capabilities, related to the ability of a company to adapt, create, develop and modify the resources base in response to environmental changes [25], [33], [39]; and the higher order capabilities that result in modification of the previous level.

In the same way Wang \& Ahmed (2007) proposed three levels. In level one, the company's capabilities are found, in level two there are the basic, essential or central capabilities, and level three the dynamics or 
organizational capacities can be found. However, Alarcón et al. (2013) distinguish technological capabilities (technological knowledge, trade secrets, the know-how generated by R\&D and specific technological intellectual capital) and marketing (corporate image, reputation and social recognition), considered important to obtain competitive advantages, since they increase the ability to discover and exploit existing opportunities. Table 4 shows the classifications of capabilities offered by the literature in detail.

Table 3. Definition of the term "capacity"

\begin{tabular}{|c|c|}
\hline Author & Concepts \\
\hline Barney (1991) & These are a resource type. \\
\hline Grant (1991) & $\begin{array}{l}\text { It is the ability of a set of resources to perform some task or activity. It is what can be done as } \\
\text { a result of resource teams working together. They are the main source of competitive } \\
\text { advantage. These are routines that interact. }\end{array}$ \\
\hline $\begin{array}{l}\text { Amit\&Schoemaker } \\
(1993)\end{array}$ & $\begin{array}{l}\text { Ability of a company to deploy resources, usually in combination, using organizational } \\
\text { processes, to achieve the desired purpose. Processes based in information, tangible or } \\
\text { intangible that are specific of the company and develop over time through complex } \\
\text { interactions between resources. }\end{array}$ \\
\hline Teece et al. (1997) & $\begin{array}{l}\text { Role of strategic management in appropriately adapting, integrating and reconfiguring } \\
\text { internal and external organizational skills, resources and functional skills to meet the needs } \\
\text { of a changing environment. }\end{array}$ \\
\hline $\begin{array}{l}\text { Helfat\&Peteraf } \\
(2003)\end{array}$ & Set of routines that involve doing an activity repeatedly or routinely. \\
\hline Ray et al. (2004) & Tangible and intangible assets that companies use to develop and implement their strategies. \\
\hline $\begin{array}{l}\text { Wang \& Ahmed } \\
(2007)\end{array}$ & $\begin{array}{l}\text { Ability of a company to deploy resources and processes encapsulate both explicit and tacit } \\
\text { knowledge incorporated in the processes. }\end{array}$ \\
\hline $\begin{array}{l}\text { Ismail, Rose, Uli, } \\
\text { \&Abdullah (2012) }\end{array}$ & Skills necessary for resource development in the organizations. \\
\hline Dávila (2013) & Integration of past experiences to solve current problems and guiding future decisions. \\
\hline $\begin{array}{l}\text { Alarcon Parra, } \\
\text { \&Garcia (2014) }\end{array}$ & $\begin{array}{l}\text { Skills coming from the collective learning of the organization, related to how to coordinate } \\
\text { the various production techniques that integrate multiple chnology flows. }\end{array}$ \\
\hline
\end{tabular}

Despite the fact that most studies on RBV highlight a strong connection between the set of $\mathrm{R} \& \mathrm{C}$ and the increases in productivity or economic and financial results [45], [46], [11], [47], or between the R\&C and the generation of competitive advantages [5], [6], [48], [49], [50], [51], [52], [53], [54], [55], [56] [57], [20], [58], [59], comparatively there are very few empirical studies on the relations between resources and capabilities themselves. In this sense, there are investigations that propose a direct influence of resources in the generation and improvement of capabilities. Helfat\&Peteraf (2003) state that capabilities have an evolutionary life cycle inherent to a work team and that they form the basis of competitive advantage. They consider that the capability starts in a group of individuals (resources), with different attributes or characteristics and an objective that implies generating a skill, then it evolves to a stage of development where it is combined with the accumulated experience. The development of capability depends on what individuals can achieve with the available resources. Finally, it enters a phase of maturity in which it is maintained through its regular execution and is incorporated into the memory of the organization.

The development of capabilities involves learning activities, integration and coexistence among the members of the company, resources and allied companies. These interactions generate new knowledge which adopted by organizations along with the knowledge acquired from past experiences, give way to new capabilities or can improve existing ones, allowing to develop competitive advantages [60]-[62]. 
Table 4. Classification of capabilities.

\begin{tabular}{|c|c|}
\hline Author & Classification \\
\hline Grant (1991) & $\begin{array}{l}\text { Organizational capabilities: individual functional capabilities (product development, market } \\
\text { research, human resource management, financial control, operations management) and core } \\
\text { competencies (Coming as a result of functional and technological integration to create } \\
\text { products). }\end{array}$ \\
\hline Hall (1993) & $\begin{array}{l}\text { Capabilities based on assets: Regulatory Capacity (property rights, contracts, trade secrets) } \\
\text { and positional capacity (reputation, setting the value chain). } \\
\text { Capabilities based on competencies: functional capacity (the result of knowledge, skills and } \\
\text { experience of employees, suppliers, distributors) and culture capacity (habits, attitudes, } \\
\text { beliefs and individuals and groups within the organization). }\end{array}$ \\
\hline Collis (1994) & Organizational capabilities. \\
\hline Teece et al. (1997) & $\begin{array}{l}\text { Capacity for timely response, fast and flexible product innovation management and } \\
\text { effectively relocating to coordinate internal and external skills, adaptive, dynamic, } \\
\text { reconfigure and transform, scanning the environment, evaluate markets and competitors. }\end{array}$ \\
\hline $\begin{array}{l}\text { Eisenhardt\& Martin } \\
(2000)\end{array}$ & Dynamic capabilities. \\
\hline Winter (2003) & $\begin{array}{l}\text { Zero level capabilities or operational or ordinary (production, product sales and new product } \\
\text { development) capabilities. } \\
\text { Class capabilities and dynamic capabilities. } \\
\text { Higher order capabilities (organizational learning). }\end{array}$ \\
\hline $\begin{array}{l}\text { Helfat\&Peteraf } \\
(2003)\end{array}$ & Operational and dynamic: organizational capabilities. \\
\hline $\begin{array}{l}\text { Wang \& Ahmed } \\
(2007)\end{array}$ & $\begin{array}{l}\text { Level One (the capabilities of the company). } \\
\text { Level two (basic essential or core capabilities of the company). } \\
\text { Level Three (dynamic capabilities or past organizational capabilities). }\end{array}$ \\
\hline $\begin{array}{l}\text { Teece (2007) } \\
\text { Cepeda \& Vera } \\
\text { (2007) }\end{array}$ & $\begin{array}{l}\text { Management skills and dynamic capabilities. } \\
\text { Operational capacity or organizational capacity and dynamic capabilities. }\end{array}$ \\
\hline $\operatorname{Kim}(2010)$ & Strategic capabilities (individual competence and organizational competence). \\
\hline $\begin{array}{l}\text { Fortune\& Mitchell } \\
\text { (2012) }\end{array}$ & $\begin{array}{l}\text { Administrativecapabilities } \\
\text { Functionalabilities }\end{array}$ \\
\hline $\begin{array}{l}\text { Alarcon et al. } \\
(2013)\end{array}$ & $\begin{array}{l}\text { Technological capabilities } \\
\text { Marketing capacity }\end{array}$ \\
\hline $\begin{array}{l}\text { ShanCai, Hatfield, } \\
\text { \&Tang (2014) }\end{array}$ & Technological innovation capacity, financial management, marketing and responsiveness. \\
\hline
\end{tabular}

\section{Method}

This study explores existing literature on the relationships between resources and capabilities in themselves. To achieve this, a complete bibliometric analysis was done. This is a discipline that applies mathematical and statistical methods to examine activity and productivity. Scientifically saying it evaluates the development of knowledge on a specific topic, scientific quality and the influence of different works and sources [63], [64], [65]. This type of analysis is completed through indicators that measure the bibliographic material in terms of productivity and impact of the publications.
The first step was choosing the Web of Science (WOS) from Thomson Reuters, since it is one of the most used databases for this type of analysis due to the quality of its scientific information. WOS journals have impact factors in the Journal Citation Report (JCR), providing academic validation to the research. The areas of knowledge included are: economy, administration and business. The indicators to be used are of quantity and quality [63], [64], [66]. The first one's measures productivity through the number of publications, the second, measures the impact of a publication in relation to the number of citations received, with this it is intended to determine 
how interest has grown in knowing the relationship between resources and capabilities in the last years.

\section{Results}

The search generated 258 documents hosted by the WOS that consider the existence of a relationship between resources and capabilities. 237 articles, 7 working documents, 17 reviews of literature, 4 categorized as editorial material, and 1 publication retracted (a public statement about a paper that is drawn). Only the number of published research articles were considered because these are the types of documents used to communicate the results of research in a clear and concise manner in scientific journals. For the period 2001 - 2016, the following items were analyzed:

- Number of articles per year.

- Countries with higher productivity.

- More productive authors.

- Magazines with the highest number of publications.

- Most cited articles.

\subsection{Articles per year}

The study of the relations between $\mathrm{R} \& \mathrm{C}$ becomes visible to the academic community since 2001, this is contrasted in two databases (WOS and Scopus), verifying that in previous years a maximum of two articles per year were published, making the period 2001 - 2016 of feasible study. Figure 1 present the number of publications per year, there is evidence that in 2001 only 6 articles were published in the WOS, a figure that increased in the following 15 years, however, its growth did not keep a clear trend. The largest number of studies was concentrated in 2010, when 27 documents were published. Between 2014 and 2015 the number of publications remained stable, while in 2016 there was again a decrease.

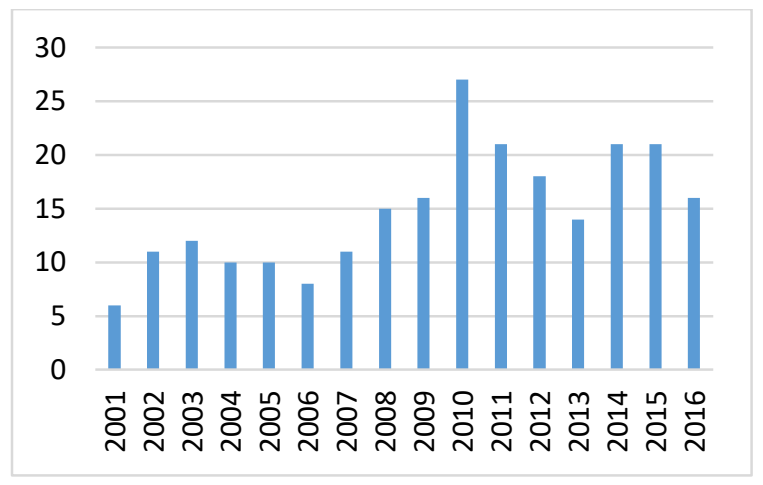

Figure 1. Trend in the study of the relationship between R\&C.

\subsection{Countries with higher productivity}

Productivity is valued through the number of published research articles (TP), the total number of citations received per published article (TC), the average citations per published article $(\mathrm{C} / \mathrm{P})$ and the $\mathrm{H}$ index that measures the quality of research production based on the number of citations received. Table 5 contains the 20 countries with the highest productivity in the subject under study. The United States ranks as the country with the highest number of publications (100 documents) with the highest number of citations $(5,122)$ and the highest $\mathrm{H}$ index $(33)$, however, the average citations per article is led by Belgium with 95,67, data that is interesting because it only counts with 3 publications; which could reflect the quality of their studies. The position of the United States may be due to factors such as the investment that the country devotes to research and the better access to scientific journals and databases by its academics compared with theoreticians from other nations. England and Spain occupy the second and third position with 24 and 18 studies respectively. Belgium, Malaysia and Portugal have the same number of publications, however, Belgium has a number of average citations per article and the highest $\mathrm{H}$ index.

The number of citations from Malaysia and Portugal could be explained by the recent of their publication, since they are found between 2011 and 2016 or because of the lower academic value of their studies.

Table 6 shows the number of studies published in the ten most productive countries between 200-2016. It is evident that the majority of articles visible in the WOS were published in the United States; however, during 2016 this figure significantly decreased, while in England, China and Australia increased (p.e. Table 6).

\subsection{Authors with higher productivity}

Table 7 presents the countries where the authors executed their research activity, together with their bibliometric indicators. The first six authors (Bowman Cliff, Hartmann Evi, Kaufmann Lutz, Duysters G, LengnickHall CA and Lengnick-Hall ML) have 3 publications each. Although they are the most productive, it is still a small number compared to studies that analyze the impact of resources and capabilities on competitive advantage (these reach, for example, 3,187 documents in the WOS). On the other hand, the most productive authors do not necessarily have the most citations, the analysis reflects that authors with lower productivity are positioned with a high number of citations as in the case of Duysters, G (408 citations), Kale Prashant (344 citations) and Hartmann Evi (245 citations). It should be 
noted that for this analysis the number of academics working in the European continent more precisely in Germany is remarkable (p.e. Table 7).

Table 5. Countries with the highest rate of productivity.

\begin{tabular}{clrrrr}
\hline Rank & Country & TP & TC & C / P & H-index \\
\hline 1 & U.S & 100 & 5,122 & 51.22 & 33 \\
2 & England & 24 & 596 & 24.83 & 11 \\
3 & Spain & 18 & 273 & 15.17 & 7 \\
4 & Australia & 15 & 217 & 14.47 & 7 \\
5 & China & 14 & 248 & 17.71 & 7 \\
6 & Taiwan & 14 & 310 & 22.14 & 9 \\
7 & Germany & 13 & 700 & 53.85 & 10 \\
8 & South Korea & 11 & 110 & 10.00 & 7 \\
9 & France & 10 & 514 & 51.40 & 9 \\
10 & Netherlands & 9 & 693 & 77.00 & 9 \\
11 & Italy & 8 & 202 & 25,25 & 3 \\
12 & Sweden & 8 & 305 & 38.12 & 6 \\
13 & Glen & 6 & 83 & 13.83 & 4 \\
14 & Denmark & 6 & 304 & 50.67 & 2 \\
15 & Brazil & 5 & 22 & 4.40 & 3 \\
16 & Singapore & 4 & 192 & 48,00 & 4 \\
17 & Turkey & 4 & 23 & 5,75 & 3 \\
18 & Belgium & 3 & 287 & 95.67 & 1 \\
19 & Malaysia & 3 & 2 & .67 & 2 \\
20 & Portugal & 3 & 8 & 2,67 & \\
\hline
\end{tabular}

Source. Web of Science.

Table 6 shows the number of studies published in the ten most productive countries between 200-2016. It is evident that the majority of articles visible in the WOS were published in the United States; however, during 2016 this figure significantly decreased, while in England, China and Australia increased (p.e. Table 6).

\subsection{Authors with higher productivity}

Table 7 presents the countries where the authors executed their research activity, together with their bibliometric indicators. The first six authors (Bowman Cliff, Hartmann Evi, Kaufmann Lutz, Duysters G, LengnickHall CA and Lengnick-Hall ML) have 3 publications each. Although they are the most productive, it is still a small number compared to studies that analyze the impact of resources and capabilities on competitive advantage (these reach, for example, 3,187 documents in the WOS). On the other hand, the most productive authors do not necessarily have the most citations, the analysis reflects that authors with lower productivity are positioned with a high number of citations as in the case of Duysters, G (408 citations), Kale Prashant (344 citations) and Hartmann Evi (245 citations). It should be noted that for this analysis the number of academics working in the European continent more precisely in Germany is remarkable (p.e. Table 7).

\subsection{Most productive magazines}

We identified 102 journals that published articles exploring the relationships between resources and capabilities. Table 8 presents the most productive journals in this sense together with its impact factor (used to know the importance of a journal within a research area). The two journals with the highest number of publications are: Strategic Management Journal and Technovation, with 12 documents each. Subsequently, three journals with 7 publications each are placed, among them: Journal of International Business Studies, R \& D 
Management and Technological Forecasting and Social Change. Although most publications focus on certain types of journals, it does not mean that they have the highest impact factor (p.e. Table 8).

Table 6. The 10 countries with the highest annual productivity.

\begin{tabular}{ccccccccccc}
\hline Year & U.S & England & Spain & Australia & China & Taiwan & Germany & $\begin{array}{c}\text { South } \\
\text { Korea }\end{array}$ & France & Netherlands \\
\hline 2001 & 3 & 0 & 0 & 2 & 1 & 0 & 0 & 0 & 0 & 0 \\
2002 & 8 & 0 & 0 & 1 & 0 & 0 & 0 & 0 & 0 & 2 \\
2003 & 6 & 0 & 0 & 0 & 0 & 1 & 0 & 0 & 2 & 1 \\
2004 & 5 & 1 & 0 & 0 & 0 & 1 & 0 & 1 & 0 & 0 \\
2005 & 8 & 1 & 0 & 0 & 0 & 1 & 0 & 0 & 0 & 0 \\
2006 & 1 & 1 & 0 & 0 & 0 & 0 & 1 & 0 & 1 & 3 \\
2007 & 2 & 2 & 0 & 0 & 0 & 2 & 0 & 0 & 1 & 0 \\
2008 & 8 & 1 & 2 & 2 & 0 & 1 & 0 & 0 & 1 & 1 \\
2009 & 10 & 1 & 1 & 2 & 1 & 0 & 1 & 1 & 2 & 0 \\
2010 & 8 & 4 & 2 & 0 & 0 & 4 & 5 & 1 & 0 & 1 \\
2011 & 7 & 2 & 3 & 0 & 1 & 0 & 2 & 2 & 1 & 0 \\
2012 & 6 & 2 & 1 & 1 & 3 & 2 & 1 & 1 & 0 & 0 \\
2013 & 8 & 1 & 1 & 1 & 2 & 1 & 0 & 2 & 1 & 1 \\
2014 & 10 & 2 & 5 & 3 & 0 & 1 & 0 & 2 & 1 & 0 \\
2015 & 9 & 1 & 1 & 0 & 2 & 0 & 3 & 0 & 0 & 0 \\
2016 & 1 & 5 & 2 & 3 & 4 & 0 & 0 & 1 & 0 \\
\hline
\end{tabular}

Source. Vantage Point Software from WOS data.

Table 7. Influential authors in the literature on relationship between R \& C.

\begin{tabular}{llllll}
\hline Authors & Country & TP & TC & C / P & H \\
\hline Bowman C & England & 3 & 42 & 14,00 & 3 \\
Hartmann E & Germany & 3 & 245 & 81.67 & 3 \\
Kaufmann L & Germany & 3 & 75 & 25,00 & 3 \\
Duysters G & Netherlands & 3 & 408 & 136 & 3 \\
Lengnick-Hall CA & U.S & 3 & 113 & 37.67 & 2 \\
Lengnick-Hall ML & U.S & 3 & 122 & 40.67 & 3 \\
Ambrosini V & England & 2 & 25 & 12,50 & 2 \\
blome C & Germany & 221 & 110.50 & 2 \\
Collier N & England & 2 & 22,00 & 2 \\
Foerstl K & Germany & 2 & 24 & 12,00 & 110.50 \\
Grimpe C & Germany & 2 & 221 & 2 \\
Hervas-Oliver JL & Spain-United States & 2 & 164 & 82.00 & 2 \\
Hyland P & Australia & 2 & 53 & 26,50 & 2 \\
Kale P & U.S & 2 & 3.4 & 17,00 & 2 \\
Lau A & China & 2 & 344 & 172.00 & 2 \\
Ruby Lee P & China-US & 2 & 80 & 40.00 & 2 \\
Lin BW & Taiwan & 2 & 15 & 7.50 & 1 \\
Manning S & U.S & 2 & 89 & 44.50 \\
Reuter C & Germany & 2 & 21 & 10,50 & 2 \\
Sofka W & Germany & 2 & 221 & 110.50 & 2 \\
\hline
\end{tabular}

Source. Web of Science. 


\subsection{Most cited articles}

The most relevant article has received 993 citations, it was published in 2003 by Helfat and Peteraf, and is entitled: The dynamic resource-based view: capability lifecycles. It should be noted that the documents found indicate different internal and external sources that generate capabilities, study the relationship between resources and capabilities, the influence of resources on capabilities and analyze the relationship of some type of resource or capacity with competitive advantage or performance of the company. Complete trends are shown in Table 9.

Table 8. Magazines with more publications.

\begin{tabular}{lllc}
\hline Rank & $\begin{array}{l}\text { Number } \\
\text { publications }\end{array}$ & Magazine & 2016 impact factor \\
\hline 1 & 12 & Strategic Management Journal & 4.461 \\
2 & 12 & Technovation & 3.265 \\
3 & 7 & Journal of International Business Studies & 5.869 \\
4 & 7 & R\& D Management & 2.444 \\
5 & 7 & Technological Forecasting and Social Change & 2.625 \\
6 & 6 & IEEE Transactions on Engineering Management & 1.188 \\
7 & 6 & International Journal of Technology Management. & 1.036 \\
8 & 5 & Industrial and Corporate Change & 1.777 \\
9 & 5 & Journal of International Marketing & 3.725 \\
10 & 5 & Journal of Supply Chain Management & 5.789 \\
11 & 5 & Journal of World Business & 3.758 \\
12 & 5 & Organization Science & 2.691 \\
13 & 5 & Research Policy & 4.495 \\
14 & 4 & Asian Journal of Technology Innovation & 0.698 \\
15 & 4 & British Journal of Management & 2.982 \\
16 & 4 & Industrial Marketing Management & 3.166 \\
17 & 4 & Innovation Management Policy \&Practice & 0.950 \\
18 & 4 & International Journal of Human Resource Management & 1.650 \\
19 & 4 & Journal of Management Studies & 3.962 \\
20 & 4 & Asian Business\& Management & 1.133 \\
\hline
\end{tabular}

Source. Web of Science.

Table 9. Most cited above relations R \& C Studies.

\begin{tabular}{llll}
\hline Rank & TC & Authors & Title \\
\hline 1 & 993 & Helfat \& Peteraf (2003) & The dynamic resource-based view: Capability lifecycles. \\
2 & 380 & Vorhies \& Morgan (2005) & Benchmarking marketing capabilities for sustainable competitive advantage. \\
3 & 332 & $\begin{array}{l}\text { Habbershon, Williams, \& } \\
\text { MacMillan (2003) }\end{array}$ & A unified systems perspective of family firm performance. \\
4 & 320 & $\begin{array}{l}\text { Ethiraj, Kale, Krishnan, \& Singh } \\
\text { (2005) }\end{array}$ & $\begin{array}{l}\text { Where do capabilities come from and how do they matter? A study in the } \\
\text { software services industry. } \\
\text { Sources of capabilities, integration and technology commercialization. }\end{array}$ \\
5 & 247 & Zahra \& Nielsen (2002) & $\begin{array}{l}\text { External sources of innovative capabilities: The preference for strategic } \\
\text { alliances or mergers and acquisitions. }\end{array}$ \\
7 & 239 & Hagedoorn \& Duysters (2002) & $\begin{array}{l}\text { Florin, Lubatkin, \& Schulze } \\
\text { A social capital model of high-growth ventures. }\end{array}$ \\
9 & 178 & $\begin{array}{l}\text { Hoffmann (2007) } \\
\text { Verona \& Ravasi (2003) }\end{array}$ & $\begin{array}{l}\text { Strategies for managing a portfolio of alliances. } \\
\text { Unbundling dynamic capabilities: an exploratory study of continuous } \\
\text { product innovation } \\
\text { Sustainable Supply Chain Management and Inter-Organizational Resources: } \\
\text { A Literature Review }\end{array}$ \\
\hline
\end{tabular}




\begin{tabular}{|c|c|c|c|}
\hline 11 & 159 & $\begin{array}{l}\text { Vanhaverbeke, Duysters, \& } \\
\text { Noorderhaven (2002) }\end{array}$ & $\begin{array}{l}\text { External technology sourcing through alliances or acquisitions: An analysis } \\
\text { of the application-specific integrated circuits industry. }\end{array}$ \\
\hline 12 & 157 & Anand \& Delios (2002) & Absolute and relative resources as determinants of international acquisitions. \\
\hline 13 & 156 & Levina \& Vaast (2008) & $\begin{array}{l}\text { Innovating or doing as told? Status differences and overlapping boundaries } \\
\text { in offshore collaboration. }\end{array}$ \\
\hline 14 & 140 & Mezias (2002) & $\begin{array}{l}\text { Identifying liabilities of foreignness and strategies to minimize their effects: } \\
\text { The case of labor lawsuit judgments in the United States. }\end{array}$ \\
\hline 15 & 137 & Fey \& Birkinshaw (2005) & External sources of knowledge, governance mode, and R\&D performance. \\
\hline 16 & 134 & Kor \& Mahoney (2005) & $\begin{array}{l}\text { How dynamics, management, and governance of resource deployments } \\
\text { influence firm-level performance. }\end{array}$ \\
\hline 17 & 122 & $\begin{array}{l}\text { Reuter, Foerstl, Hartmann, \& } \\
\text { Blome (2010) }\end{array}$ & $\begin{array}{l}\text { Sustainable global supplier management: the role of dynamic capabilities in } \\
\text { achieving competitive advantage. }\end{array}$ \\
\hline 18 & 122 & Sole \& Edmondson (2002) & Situated knowledge and learning in dispersed teams. \\
\hline 19 & 117 & Easterby-Smith \& Prieto (2008) & $\begin{array}{l}\text { Dynamic capabilities and knowledge management: } i \text { an integrative role for } \\
\text { learning? }\end{array}$ \\
\hline 20 & 100 & Sheu (2010) & $\begin{array}{l}\text { Dynamic relief-demand management for emergency logistics operations } \\
\text { under large-scale disasters. }\end{array}$ \\
\hline 21 & 99 & $\begin{array}{l}\text { Foerstl, Reuter, Hartmann, \& } \\
\text { Blome (2010) }\end{array}$ & $\begin{array}{l}\text { Managing supplier sustainability risks in a dynamically changing } \\
\text { environment-Sustainable supplier management in the chemical industry. }\end{array}$ \\
\hline 22 & 96 & Grimpe \& Sofka (2009) & $\begin{array}{l}\text { Search patterns and absorptive capacity: Low-and high-Technology sectors } \\
\text { in European countries. }\end{array}$ \\
\hline 23 & 95 & $\begin{array}{l}\text { Wang, Hong, Kafouros, \& } \\
\text { Wright (2012) }\end{array}$ & $\begin{array}{l}\text { Exploring the role of government involvement in outward FDI from } \\
\text { emerging economies. }\end{array}$ \\
\hline 24 & 82 & Jones, Lanctot, \& Teegen (2001) & Determinants and performance impacts of external technology acquisition. \\
\hline 25 & 79 & Dehning \& Stratopoulos (2003) & $\begin{array}{l}\text { Determinants of a sustainable competitive advantage due to an IT-enabled } \\
\text { strategy. }\end{array}$ \\
\hline 26 & 73 & Yam, Lo, Tang, \& Lau (2011) & $\begin{array}{l}\text { Analysis of sources of innovation, technological innovation capabilities, and } \\
\text { performance: An empirical study of Hong Kong manufacturing industries. }\end{array}$ \\
\hline 27 & 73 & Kolk \& Pinkse (2008) & $\begin{array}{l}\text { A perspective on multinational enterprises and climate change: Learning } \\
\text { from an inconvenient truth? }\end{array}$ \\
\hline 28 & 69 & Chadwick \& Dabu (2009) & $\begin{array}{l}\text { Human Resources, Human Resource Management, and the Competitive } \\
\text { Advantage of Firms: Toward a More Comprehensive Model of Causal } \\
\text { Linkages. }\end{array}$ \\
\hline 29 & 69 & $\begin{array}{l}\text { Lengnick-Hall, Lengnick-Hall, } \\
\text { \& Abdinnour-Helm (2004) }\end{array}$ & $\begin{array}{l}\text { The role of social and intellectual capital in achieving competitive advantage } \\
\text { through enterprise resource planning (ERP) systems. }\end{array}$ \\
\hline 30 & 68 & Sofka \& Grimpe (2010) & Specialized search and innovation performance - evidence across Europe. \\
\hline 31 & 66 & West \& Noel (2009) & The Impact of Knowledge Resources on New Venture Performance. \\
\hline 32 & 63 & Matear, Gray, \& Garrett (2004) & $\begin{array}{l}\text { Market orientation, brand investment, new service development, market } \\
\text { position and performance for service organizations. }\end{array}$ \\
\hline 33 & 60 & $\begin{array}{l}\text { Simsek, Veiga, \& Lubatkin } \\
(2007)\end{array}$ & $\begin{array}{l}\text { The impact of managerial environmental perceptions on corporate } \\
\text { entrepreneurship: Towards understanding discretionary slack's pivotal role. }\end{array}$ \\
\hline 34 & 60 & $\begin{array}{l}\text { Wynstra, Axelsson, \& Van Der } \\
\text { Valk (2006) }\end{array}$ & $\begin{array}{l}\text { An application-based classification to understand buyer-supplier interaction } \\
\text { in business services. }\end{array}$ \\
\hline
\end{tabular}




\begin{tabular}{|c|c|c|c|}
\hline 35 & 56 & $\begin{array}{l}\text { Di Gregorio, Musteen, \& } \\
\text { Thomas (2009) }\end{array}$ & Offshore outsourcing as a source of international competitiveness for SMEs. \\
\hline 36 & 55 & Lin (2003) & $\begin{array}{l}\text { Technology transfer as technological learning: a source of competitive } \\
\text { advantage for firms with limited R\&D resources. }\end{array}$ \\
\hline 37 & 54 & Huggins \& Johnston (2010) & $\begin{array}{l}\text { Knowledge flow and inter-firm networks: The influence of network } \\
\text { resources, spatial proximity and firm size. }\end{array}$ \\
\hline 38 & 53 & $\begin{array}{l}\text { Ehrgott, Reimann, Kaufmann, \& } \\
\text { Carter (2011) }\end{array}$ & Social Sustainability in Selecting Emerging Economy Suppliers. \\
\hline 39 & 52 & $\begin{array}{l}\text { Walsh, Boylan, McDermott, \& } \\
\text { Paulson (2005) }\end{array}$ & $\begin{array}{l}\text { The semiconductor silicon industry roadmap: Epochs driven by the } \\
\text { dynamics between disruptive technologies and core competencies. }\end{array}$ \\
\hline 40 & 50 & Luo, Sivakumar, \& Liu (2005) & Globalization, marketing resources, and performance: Evidence from China. \\
\hline 41 & 49 & Mikkola (2007) & $\begin{array}{l}\text { Management of product architecture modularity for mass customization: } \\
\text { Modeling and theoretical considerations. }\end{array}$ \\
\hline 42 & 48 & Petit (2012) & Project portfolios in dynamic environments: Organizing for uncertainty. \\
\hline 43 & 48 & McKelvie \& Davidsson (2009) & $\begin{array}{l}\text { From Resource Base to Dynamic Capabilities: an Investigation of New } \\
\text { Firms. }\end{array}$ \\
\hline 44 & 44 & Wu, Melnyk, \& Flynn (2010) & Operational Capabilities: The Secret Ingredient. \\
\hline 45 & 44 & $\begin{array}{l}\text { Lengnick-Hall \& Lengnick-Hall } \\
\text { (2003) }\end{array}$ & HR's role in building relationship networks. \\
\hline 46 & 43 & Saxton \& Dollinger (2004) & $\begin{array}{l}\text { Target reputation and approvability: Picking and deploying resources in } \\
\text { acquisitions. }\end{array}$ \\
\hline 47 & 41 & Macher \& Mowery (2009) & $\begin{array}{l}\text { Measuring Dynamic Capabilities: Practices and Performance in } \\
\text { Semiconductor Manufacturing. }\end{array}$ \\
\hline 48 & 39 & $\begin{array}{l}\text { Koufteros, Vickery, \& Dröge } \\
\text { (2012) }\end{array}$ & $\begin{array}{l}\text { The Effects of Strategic Supplier Selection on Buyer Competitive } \\
\text { Performance in Matched Domains: Does Supplier Integration Mediate the } \\
\text { Relationships. }\end{array}$ \\
\hline 49 & 38 & $\begin{array}{l}\text { DeSarbo, Di Benedetto, Jedidi, \& } \\
\text { Song (2006) }\end{array}$ & $\begin{array}{l}\text { Identifying sources of heterogeneity for empirically deriving strategic types: } \\
\text { A constrained finite-mixture structural-equation methodology. }\end{array}$ \\
\hline 50 & 36 & Kogut \& Zander (2003) & $\begin{array}{l}\text { A memoir and reflection: knowledge and an evolutionary theory of the } \\
\text { multinational firm } 10 \text { years later. }\end{array}$ \\
\hline
\end{tabular}

\section{Research agenda}

This bibliometric analysis concludes that the research on the impact of resources on capabilities is still scarce in the literature. The research is focused on the study of the impact of resources and capabilities on the competitive advantage or performance of companies. 25 articles out of the 50 most cited indeed, address this issue. On the other way, 18 articles studied capabilities as sources of other capabilities.

Although the theoretical literature is clear about the approach that resources are generating capabilities, and these might turn into competitive advantages [18], [23], [27], [28], [67], [68], empirical research on resources as antecedents of capabilities is still scarce. It is considered that the research agenda derived from this paper should focus on the role of resources as an important source in the development of capabilities, given that this issue has not been addressed in depth and is relevant for companies. In a concrete way, it is suggested to approach the empirical study by dividing into the resources and capabilities by their typologies, for example: tangible or intangible resources and organizational or dynamic capabilities, as well as to initiate a study about what type of resources are precursors of what kind of capabilities. It might be considered that, in companies of different sectors, the results might not be the same, therefore, an appropriate strategy would be to aggregate by industrial activity.

\section{Conclusions}

This research reveals the results of previous works on the relationship between resources and capabilities between 2001 and 2016, available in the Web of Science. The results provide an overview of the evolution of the study of the subject, which serve as a guide for future 
researchers who wish to delve into the analysis of the relationship between resources and capabilities of companies. The document analyzes in detail the trends in the study period. It is noted that the predominant documents types in the WOS are articles (237). The findings reveal that for the year 2010 productivity in this particular area of knowledge experienced an increase (27 published documents), a figure that decreased in the following six years. It is also evident that 100 articles were published in the United States during the study period, ranking as the most productive country with the highest number of citations $(5,122)$. The authors maintain a homogeneous productivity level (2 to 3 publications) and a fairly similar $\mathrm{H}$-index (2 to 3 ). The journals with the highest number of publications are Strategic Management Journal and Technovation with 12 documents each, however these publications do not have the greatest impact factor. The most cited article was published in 2003 and has 993 citations. Finally, this analysis points out that research on the relationships between resources and capabilities have not been adequately explored, and this subject is indeed, in its initial stages, considering the importance of resources as generators of capabilities and the potential of them as sources of business competitiveness. It is suggested that for future studies impact or causality relationships be explored among different types of resources and capabilities making a sectorial distinction, since it is foreseen that for different sectors, the impact that resources may have on capabilities varies significantly.

\section{Limitations}

This study presents a series of limitations, on the one hand, a single database was used, excluding other bases with indexed journals, and even, with non-indexed publications that could contain related articles. Future analyzes of this type could take into account additional databases such as Scopus and Google Scholar, since they also have valuable research content. However, when defining the specific areas of the study, other areas that could possibly address the issue were not taken into account. Finally, it should be noted that the high citation figures that an author receives give him certain status so that other scholars may cite his work without prior review of the content. In the same sense, recent publications have little or no citation, giving them less relevance, since they require time to value themselves and become influential in the field.

\section{References}

[1] R. M. Grant, "The Resource-Based Theory of Competitive Advantage: Implications for Strategy Formulation," Calif. Manage. Rev., vol. 33, no. 3, pp.
$114-135,1991$.

[2] C. E. Helfat and M. A. Peteraf, "The dynamic resource-based view: Capability lifecycles.," Strateg. Manag. J., vol. 24, no. 10, pp. 997-1010, 2003.

[3] S. L. Newbert, "Empirical research on the resourcebased view of the firm: an assessment and seggestions for future research," Strateg. Manag. J., vol. 28, pp. 121146, 2007.

[4] M. A. Peteraf, "The cornerstones of competitive advantage: A resource-based view," Strateg. Manag. J., vol. 14, no. 3, pp. 179-191, 1993.

[5] J. B. Barney, "Firm Resources and Sustained Competitive Advantage," J. Manage., vol. 17, no. 1, pp. 99-120, 1991.

[6] J. B. Barney, "Resource-based theories of competitive advantage: A ten-year retrospective on the resource-based view.," J. Manage., vol. 27, pp. 643-650, 2001.

[7] J. B. Barney, "Is the resource-based 'view' a useful perspective for strategic management research? Yes," Acad. Manag. Rev., vol. 26, no. 1, pp. 41-56, 2001.

[8] J. B. Barney and A. M. Arikan, The resource-based view: origins and implications. 2001.

[9] R. Hall, "A framework linking intangible resources and capabilities to sustainable competitive advantage," Strateg. Manag. J., vol. 14, no. 8, pp. 607-618, 1993.

[10] J. E. Navas and L. A. Guerras, La dirección estratégica de la empresa. Teoría y aplicaciones, 3rd ed. Madrid, 2002.

[11] G. Ray, J. B. Barney, and W. A. Muhanna, "Capabilities, business processes, and competitive advantage: Choosing the dependent variable in empirical tests of the resource-based view," Strateg. Manag. J., vol. 25, no. 1, pp. 23-37, 2004.

[12] C. L. Wang and P. K. Ahmed, "Dynamic capabilities: A review and research agenda," Int. J. Manag. Rev., vol. 9, no. 1, pp. 31-51, 2007.

[13] R. Amit and P. J. Schoemaker, "Strategic assets and organizational rent raphael," Strateg. Manag. J., vol. 14, no. 1, pp. 33-46, 1993.

[14] R. M. Grant, Dirección estratégica. Conceptos, técnicas y aplicaciones. Madrid: Civitas, 1996. 
[15] P. Huerta, J. E. Navas, and P. Almodóvar, "La Diversificación desde la Teoría de Recursos y Capacidades," Cuad. Estud. Empres., vol. 14, pp. 87104, 2004.

[16] S. Schriber and J. Löwstedt, "Tangible resources and the development of organizational capabilities," Scand. J. Manag., vol. 31, pp. 54-68, 2015.

[17] E. T. Penrose, The Theory of the Growth of the Firm. New York: Jhon Wiley, 1959.

[18] R. Amit and P. Schoemaker, "Strategic assets and organizational rent.," Strateg. Manag. J., vol. 1, no. 14, pp. 33-46, 1993.

[19] I. Barreto, "Dynamic Capabilities: A Review of Past Research and an Agenda for the Future," $J$. Manage., vol. 36, no. 1, pp. 256-280, 2010.

[20] B. Wernerfelt, "A resource-based view of the firm.," StraStrategic Manag. J., vol. 5, no. 2, pp. 171180, 1984.

[21] M. Torres-Barreto, "Product innovations and R \& D public funding: How to handle heteroscedasticity and autocorrelation," I+D Revista de Investigaciones, vol.9 no. 1, pp. 138-145, 2017.

[22] D. J. Teece, G. Pisano, and A. Shuen, "Dynamic Capabilities and Strategic Management," StraStrategic Manag. J., vol. 18, no. 7, pp. 509-533, 1997.

[23] D. J. Teece and G. Pisano, "The Dynamic Capabilities of Firms: An Introduction", Industrial \& Corporate Change," Ind. Corp. Chang., vol. 3, no. 3, pp. 537-556, 1994.

[24] D. J. Teece, "Explicating Dynamic Capabilities: The Nature and Microfoundations of (Sustainable) Enterprise Performance," StraStrategic Manag. J., vol. 28, no. 13, pp. 1319-1350, 2007.

[25] K. M. Eisenhardt and J. A. Martin, "Dynamic capabilities: what are they?," Strateg. Manag. J., vol. 21, pp. 1105-1121, 2000.

[26] B. Wernerfelt, "From critical resources to corporate strategy," J. Gen. Manag., vol. 14, no. 3, pp. 412, 1989.

[27] S. A. Zahra, H. J. Sapienza, and P. Davidsson, "Entrepreneurship and Dynamic Capbilities: A Review, Model and Research Agenda," J. Manag. Stud., vol. 43, no. 4, pp. 917-955, 2006.
[28] M. Zollo and S. G. Winter, "Deliberate Learning and the evolution of dynamic capabilities," Organ. Sci., vol. 13, no. 3, pp. 339-351, 2002.

[29] M. Torres-Barreto, R. Mendez-Duron, and F. Hernandez-Perlines, "Technological impact of R\&D grants on utility models," $R \& D$ Manag., vol. 46, no. S2, pp. 537-551, 2016.

[30] R. R. Nelson and S. G. Winter, An evolutionary theory of economic change. Cambridge, MA.: Harvard University Press, 1982.

[31] V. Wohlgemuth and M. Wenzel, "Dynamic capabilities and routinization," J. Bus. Res., vol. 69, no. 5, pp. 1944-1948, 2016.

[32] S. G. Winter, "Understanding dynamic capabilities," Strateg. Manag. J., vol. 24, no. 10, pp. 991995, 2003.

[33] C. E. Helfat, S. Finkelstein, W. Mitchell, M. A. Peteraf, H. Singh, D. J. Teece, and S. G. Winter, Dynamic capabilities: Understanding strategic change in organizations. Malden, MA: Blackwell Publishing, 2007.

[34] A. I. Ismail, R. C. Rose, J. Uli, and H. Abdullah, "THE RELATIONSHIP BETWEEN ORGANISATIONAL RESOURCES, CAPABILITIES, SYSTEMS AND COMPETITIVE ADVANTAGE," Asian Acad. Manag. J., vol. 17, no. 1, pp. 151-173, 2012.

[35] J. Dávila, "Capacidades organizacionales: dinámicas por naturaleza," Cuad. Adm., vol. 26, no. 47, pp. 11-33, 2013.

[36] J. R. Alarcón, G. Parra, and P. M. García, "Efectividad de la orientación emprendedora: el papel del capital social y las capacidades," Investig. Eur. Dir. y Econ. la Empres., vol. 20, pp. 131-139, 2013.

[37] G. Schreyödd and M. Kliesch-Eberl, "HOW DYNAMIC CAN ORGANIZATIONAL CAPABILITIES BE? TOWARDS A DUAL-PROCESS MODEL OF CAPABILITY DYNAMIZATION," StraStrategic Manag. J., vol. 28, pp. 913--933, 2007.

[38] M. Carattoli, "Capacidades Dinámicas: Líneas promisorias y desafíos de investigación," Cuad. Adm., vol. 26, no. 47, pp. 165-204, 2013.

[39] J. Giniuniene and L. Jurksiene, "Dynamic Capabilities, Innovation and Organizational Learning: Interrelations and Impact on Firm Performance," 
Procedia -Social Behav. Sci., vol. 213, pp. 985-991, 2015.

[40] D. J. Collis, "Research Note: How Valuable are Organizational Capabilities?," Strateg. Manag. J., vol. 15, no. S1, pp. 143-152, 1994.

[41] G. Cepeda and D. Vera, "Dynamic capabilities and operational capabilities: A knowledge management perspective," J. Bus. Res., vol. 60, no. 5, pp. 426-437, 2007.

[42] A. Kim, "Exploring the linkages between strategic capabilities and hrm in the Korean management consulting industry.," 2010.

[43] A. Fortune and W. Mitchell, "Unpacking firm exit at the firm and industry levels: The adaptation and selection of firms capabilities," Strateg. Manag. J., vol. 33, pp. 794-819, 2012.

[44] B. Shan, L. Cai, D. E. Hatfield, and S. Tang, "The relationship between resources and capabilities of new ventures in emerging economies," Inf. Technol. Manag., vol. 15, no. 2, pp. 99-108, 2014.

[45] J. Cruz, P. López, and G. Martín, "La Influencia de las Capacidades Dinámicas sobre los Resultados Financieros de la Empresa," Cuad. Estud. Empres., vol. 19, no. 19, pp. 105-128, 2009.

[46] D. M. Escandón, A. Rodriguez, and M. Hernández, "La importancia de las capacidades dinámicas en las empresas born global colombianas," Cuad. Adm., vol. 26, no. 47, pp. 141-163, 2013.

[47] H. A. Rivera and L. S. Figueroa, "Capacidades Dinámicas, una fuente de ventaja competitiva," Criterio Libr., vol. 11, no. 19, pp. 245-261, 2013.

[48] J. B. Barney, Gaining and sustaining competitive advantage, 3rd ed. Upper Saddle River, New Jersey: Pearson Education, 2007.

[49] I. Dierickx and K. Cool, "Asset stock accumulation and sustainability of competitive advantage.," Manage. Sci., vol. 35, no. 12, pp. 15041511, 1989.

[50] A. W. King, "Disentangling interfirm and intrafirm causal ambiguity: A conceptual model of causal ambiguity and sustainable competitive advantage," Acad. Manag. Rev., vol. 32, no. 1, pp. 156-178, 2007.

[51] H. Ma, "Creation and preemption for competitive advantage," Manag. Decis., vol. 37, no. 3, pp. 259-267, 1999.

[52] H. Ma, "Anatomy of competitive advantage: A SELECT framework.," Manag. Decis., vol. 37, no. 9, pp. 709-718, 1999.

[53] N. A. Morgan, A. Kaleka, and C. S. Katsikeas, "Antecedents of export venture performance: A theoretical model and empirical assessment," J. Mark., vol. 68, pp. 90-108, 2004.

[54] K. Phusavat and R. Kanchana, "Competitive priorities of manufacturing firms in Thailand.," Ind. Manag. Data Syst., vol. 107, no. 7, pp. 979-996, 2007.

[55] R. L. Priem and J. E. Butler, "Tautology in the resource-based view and the implications of externally determined resource value: Further comment," Acad. Manag. Rev., vol. 26, pp. 57-66, 2001.

[56] R. L. Priem and J. E. Butler, "Is the resourcebased 'view' a useful perspective for strategic management research?," Acad. Manag. Rev., vol. 26, pp. 22-40, 2001.

[57] A. S. Santhapparaj, J. Sreenivasan, and J. C. K. Loong, "Competitive factors of semiconductor industry in Malaysia: The managers' perspectives," Compet. Rev., vol. 16, no. 3\&4, pp. 197-211, 2006.

[58] D. G. Sirmon, M. A. Hitt, and R. D. Ireland, "Managing firm resources in dynamic environments to create value: Looking inside the black box," Acad. Manag. Rev., vol. 32, no. 1, pp. 273-292, 2007.

[59] J. Wiklund and D. Shepherd, "Knowledge-based resources, entrepreneurial orientation, and the performance of small and medium-sized businesses," Strateg. Manag. J., vol. 24, no. 1, pp. 307-1314, 2003.

[60] R. M. Grant, "Prospering in dynamicallycompetitive environments: Organizational capability knowledge integration," Organ. Sci., vol. 7, no. 4, pp. 375-387, 1996.

[61] J. Olea-Miranda, O. Contreras, and M. Barcelo, "Las capacidades de absorción del conocimiento como ventajas competitivas para la inserción de pymes en cadenas globales de valor," Estud. gerenciales, 2016.

[62] M. Porter and N. Siggelkow, "Contextuality within activity systems and sustainability of competitive advantage.," Acad. Manag. Perspect., vol. 22, no. 2, pp. 34-56, 2008. 
[63] G. Albort-Morant, A. L. Leal-Rodríguez, V. Fernández-Rodríguez, and A. Ariza-Montes, "Assessing the origins, evolution and prospects of the literature on dynamic capabilities: A bibliometric analysis," Eur. Res. Manag. Bus. Econ., 2017.

[64] G. Albort-Morant and D. Ribeiro-Soriano, "A bibliometric analysis of international impact of business incubators," J. Bus. Res., vol. 69, no. 5, pp. 1775-1779, 2016.

[65] T. U. Daim, G. Rueda, H. Martin, and P. Gerdsri, "Forecasting emerging technologies: Use of bibliometrics and patent analysis.," Technol. Forecast. Soc. Change, vol. 73, no. 8, pp. 981-1012, 2006.

[66] L. Cadavid-Higuita, G. Awad, and C. J. FrancoCardona, "A bibliometric analysis of a modeled field for disseminating innovation," Estud. Gerenciales, no. 28, pp. 213-236, 2012.

[67] S. K. Ethiraj, P. Kale, M. S. Krishnan, and J. V. Singh, "Where do capabilities come from and how do they matter? A study in the software services industry," Strateg. Manag. J., vol. 26, no. 1, pp. 25-45, 2005.

[68] A. McKelvie and P. Davidsson, "From resource base to dynamic capabilities: an investigation of new firms," Br. J. Manag., vol. 20, no. 1, 2009.

[69] Lache, L., León, A. P., Bravo, E., Becerra, L. E., \& Forero, D. "Las tecnologías de información y comunicación como prácticas de referencia en la gestión de conocimiento: una revisión sistemática de la literatura,". Rev. UIS Ing., vol. 15, no. 2, pp.27-40, 2016.

[70] M. Torres-Barreto, J. N. Martínez, L. C. MezaAriza, \& L. P. Molina, "El cambio tecnológico en el caso de los textiles inteligentes: Una aproximación desde las capacidades dinámicas," Espacios, vol. 37, no. 8, 2016. 